\title{
In vitro and in vivo study on prevention of myocardial ischemic injury by taurine
}

\author{
Fengyun Ren ${ }^{1, \#}$, Xing Liu ${ }^{3 \#}$, Xiaoxue Liu ${ }^{2}$, Yanli $\mathrm{Cao}^{2}$, Lantao $\mathrm{Liu}^{2}$, Xingjiang $\mathrm{Li}^{3}$, Yingjun $\mathrm{Wu}^{2}, \mathrm{Shudi}^{2}$, \\ Guozhong Tian ${ }^{1}$, Jing $\mathrm{Hu}^{2}$ \\ ${ }^{1}$ Department of Anatomy, School of Basic Medicine, Jiamusi University, Jiamusi, China; ${ }^{2}$ School of Basic Medicine, Mudanjiang Medical University, \\ Mudanjiang, China; ${ }^{3}$ Department of Anatomy, School of Basic Medicine, Mudanjiang Medical University, Mudanjiang, China \\ Contributions: (I) Conception and design: J Hu, G Tian; (II) Administrative support: F Ren, X Liu, Y Cao; (III) Provision of study materials or \\ patients: X Liu, X Li, Y Wu; (IV) Collection and assembly of data: F Ren, J Hu, S Du; (V) Data analysis and interpretation: J Hu, F Ren, L Liu; (VI) \\ Manuscript writing: All authors; (VII) Final approval of manuscript: All authors. \\ \#These authors contributed equally to this work. \\ Correspondence to: Guozhong Tian. Department of Anatomy, School of Basic Medicine, Jiamusi University, Jiamusi 154000, China. Email: tgz1966@163.com; \\ Jing Hu. School of Basic Medicine, Mudanjiang Medical University, Mudanjiang 157011, China. Email: jinghu_2001@hotmail.com.
}

Background: Myocardial ischemia (MI) often causes angina, arrhythmia, and cardiac insufficiency, sometimes resulting in death. Ischemia-induced myocardial tissue damage is attributed to the hypoxic damage of myocardial cells producing apoptosis and decreased proliferation. Taurine has been shown to improve MI, but its mechanism is largely unknown.

Methods: In this study, the relationship between taurine and severity of MI in vivo was evaluated by quantifying myocardial infarct areas and metabolic indicators of myocardial damage and measuring taurine levels in cardiac muscle and plasma by high performance liquid chromatography (HPLC). To elucidate how taurine might suppress ischemic injury, we established an in vitro ischemia model with isolated primary rat cardiomyocytes cultured without serum or glucose and under hypoxia. We evaluated the indicators of MI and damage, including lactic dehydrogenase (LDH), creatine kinase (CK), and cardiac troponin I (cTnI). We also examined the levels of taurine transporter (TauT), cysteine dioxygenase (CDO), and cysteine sulfinate decarboxylase (CSD) proteins involved in transport and synthesis of taurine in the myocardium and those of 2 apoptosis-associated proteins, namely, Bcl-2 associated X protein (BAX) and B-cell lymphoma-2 (Bcl-2).

Results: Exposure of myocardial cells to ischemia led to the decrease of taurine content, the suppression of cell proliferation, and led to calcium ion overload and apoptosis. Pretreatment with taurine alleviated the ischemic damage, with concomitant elevation of intracellular taurine concentrations. Molecular mechanism analysis showed that pretreatment with taurine upregulated the TauT, CDO, and CSD, 2 ratelimiting enzymes involved in taurine synthesis. These effects facilitated both taurine transport into cells and taurine synthesis, leading to taurine accumulation. In addition, apoptosis inhibition by taurine appeared to be mediated by upregulated Bcl-2 and downregulated BAX, as well as inhibition of calcium overload by suppression of calcium binding protein.

Conclusions: We demonstrated that TauT is critical for the attenuation of myocardial ischemic damage by taurine, facilitating taurine absorption and synthesis. These findings provided new insights and a theoretical foundation for future studies examining taurine as a potential treatment for MI.

Keywords: Taurine; myocardial ischemia (MI); taurine transporter (TauT); cysteine dioxygenase (CDO); cysteine sulfinate decarboxylase (CSD)

Submitted Apr 14, 2021. Accepted for publication Jun 15, 2021.

doi: 10.21037/atm-21-2481

View this article at: https://dx.doi.org/10.21037/atm-21-2481 


\section{Introduction}

Myocardial ischemia (MI) is a common life-threating disease with many adverse effects on the heart. It manifests as angina, arrhythmia, and cardiac insufficiency because of impaired aerobic metabolism in myocardial cells and the resulting limited energy supply. Taurine, the free amino acid most abundant in excitable tissues, has multiple functions, including maintaining cellular calcium homeostasis, preventing calcium overload, promoting cell proliferation and differentiation, stabilizing cell membranes, scavenging free radicals, and protecting cells from lipid peroxidation (1). Taurine is present in sites including the brain, heart, liver, kidney, bone, and muscle, where it stabilizes these tissues and protects the cells. Because of its sulfo group, taurine cannot be integrated into proteins, so it always exists in a free state. Taurine accounts for about $50-60 \%$ of the total free amino acids in myocardial tissue, and is most abundant inside cells. Intracellular taurine concentrations have been estimated at 10- to several thousand-fold greater than its extracellular levels (2).

Taurine administration has been shown to protect ischemic myocardium $(3,4)$, and taurine could inhibit MI/ reperfusion-induced apoptosis by downregulating expression of PUMA (5), but its optimal dose and mechanism of action are largely unknown. Previous studies have shown that taurine pretreatment elevated taurine transporter (TauT) messenger RNA (mRNA) and protein levels in the myocardium of a rat model of acute MI (6). Therefore, The key purpose of our present study was to investigate whether there is a concomitant or causal relationship between TauT and taurine, as well as to gather more experimental evidence for taurine-induced improvements in cardiac function.

In this study, we confirmed the protective effects of taurine in MI in vivo, in a rat model of MI. After pretreatment of the rats with taurine, we evaluated the indicators of $\mathrm{MI}$ and damage, including lactic dehydrogenase $(\mathrm{LDH})$, creatine kinase $(\mathrm{CK})$, and cardiac troponin I (cTnI), as well as myocardial infarct areas. We evaluated relationships between taurine treatment and improvements in ischemia-induced myocardial injury by measuring taurine levels in rat cardiac muscle and plasma by high performance liquid chromatography (HPLC). We also examined the levels of TauT, cysteine dioxygenase (CDO), and cysteine sulfinate decarboxylase (CSD) proteins involved in transport and synthesis of taurine in the myocardium and those of 2 apoptosis-associated proteins, namely, Bcl-2 associated $\mathrm{X}$ protein (BAX) and B-cell lymphoma-2 (Bcl-2). The levels of these proteins were related to protection against myocardial damage by taurine.

Based on this, we conducted a preliminary study in vitro to address the mechanism by which taurine could improve MI. To investigate the crucial role of TauT, we used an in vitro ischemic model with isolated primary rat cardiomyocytes cultured without serum or glucose and under hypoxic conditions. Some cells were shown to have knocked down or overexpressed TauT using a lentiviral system. Cells were pretreated with taurine and assessed for intracellular taurine concentrations, levels of taurine transport- and synthesis-associated proteins, myocardial damage indicators, apoptosis and levels of apoptosis associated proteins, calcium and calcium binding protein levels, and cell proliferation.

Together, these data addressed 2 questions: (I) whether taurine would upregulate the expression of TauT or CDO and CSD, 2 rate-limiting enzymes involved in taurine synthesis; and (II) whether intracellular calcium levels and expression of apoptotic proteins were involved in the protection of myocardial tissue against ischemia-induced damage by taurine.

We hypothesized that if taurine treatment did increase the intracellular taurine concentrations in ischemic myocardial cells by upregulation of TauT expression to transport more taurine, thus further protecting the cells, our research would provide new options for treating acute MI.

We present the following article in accordance with the ARRIVE reporting checklist (available at https://dx.doi. org/10.21037/atm-21-2481).

\section{Methods}

\section{Rat model of MI}

A total of 50 Sprague-Dawley (SD) rats, weighing $180 \pm 20$ g, were purchased from Shanghai SLAC Laboratory Animal Co., Ltd., and animal procedures were conducted in compliance with the principles of Good Laboratory Practice (GLP). All studies involving animal samples were conducted in compliance with the National Guidelines for the Care and Use of Animals in Biomedical Research and were reviewed and approved by the Ethics Committee of Mudanjiang Medical University (No. 2018030097). After a week of acclimatization, rats in acceptable physical condition were randomly divided into 5 groups: sham-operated group; taurine group (pretreatment with $200 \mathrm{mg} / \mathrm{kg}$ taurine for $3 \mathrm{~d}$ before the sham operation); MI group (ligation of 
the proximal $1 / 3$ of the left anterior descending coronary artery after thoracotomy); taurine + MI group (pretreatment with $200 \mathrm{mg} / \mathrm{kg}$ taurine for $3 \mathrm{~d}$ before thoracotomy and ligation of the proximal $1 / 3$ of the left anterior descending coronary artery); and mild MI group (ligation of the proximal $2 / 3$ of the left anterior descending coronary artery after thoracotomy). The procedure was performed as described previously (7-9) and the sham-operated group underwent the same procedure, however without ligation of the left anterior descending coronary artery. The model was confirmed by assessing the myocardial infarct area and levels of the metabolic indicators, $\mathrm{LDH}, \mathrm{CK}$, and cTnI in myocardial tissue and plasma.

\section{Analysis of taurine content in myocardial tissue and plasma}

Myocardial tissue and plasma samples were obtained from 5 rats in each group at 0.5 and $2 \mathrm{~h}$ after MI, and taurine levels in myocardial tissue and plasma were determined by HPLC.

\section{Detection of TauT, CDO, and CSD protein expression in myocardial tissue}

After $2 \mathrm{~h}$ of MI, myocardial tissue was obtained from each of the 5 rats in each group and total protein was extracted. Expression of TauT, CDO, and CSD was detected in these samples by western blot.

\section{Assessment of metabolic indicators of myocardial cell injury}

At $2 \mathrm{~h}$ after MI, blood was collected through a femoral artery cannula and was incubated for $30 \mathrm{~min}$ at $4{ }^{\circ} \mathrm{C}$. The levels of LDH, CK, and cTnI were analyzed on a BT-3000 (Biotecnica Instruments, Rome, Italy).

\section{Studies on reduction of MI-induced myocardial infarct areas by taurine}

At $2 \mathrm{~h}$ after MI, 2\% Evan's blue (EB) was injected through an internal jugular vein cannula and the cardiac muscle tissue was collected and cut into pieces from the apex cordis to the ligation site $(2 \mathrm{~mm} \times 6$ pieces). Tissue pieces were incubated in $1 \%$ 2,3,5-Triphenyltetrazolium chloride (TTC) at $37{ }^{\circ} \mathrm{C}$ for $15 \mathrm{~min}$, then fixed in $4 \%$ paraformaldehyde. In each, the pale area was quantified as infarcted (INF), the red area as area-at-risk (AAR), and the blue area as not-at-risk. The ratio of INF/AAR was used to express the area of infarction.

\section{Determination of levels of relevant proteins in myocardial tissue}

After $2 \mathrm{~h} \mathrm{MI}$, myocardial tissue was harvested from rats and total protein was extracted. Western blotting was used to detect the apoptosis related proteins Bcl-2 and BAX as well as the L-type calcium channel.

\section{Isolation and culture of rat primary myocardial cells}

Neonatal rats (from the Experimental Animal Center of the Second Military Medical University), after being immersed in $75 \%$ ethanol for $5 \mathrm{~min}$, were cut under the sternum. The hearts were removed and placed in precooled Hank's solution. Blood clots and fibrous tissue were removed and the hearts were each washed 3 times with precooled Hank's solution, placed in a $15 \mathrm{~mL}$ centrifuge tube with $1 \mathrm{~mL} 0.06 \%$ trypsin and minced into $1 \mathrm{~mm}^{3}$ pieces. The tissue pieces were then suspended in $5 \mathrm{~mL} 0.06 \%$ trypsin and incubated at $37^{\circ} \mathrm{C}$ for $10 \mathrm{~min}$. The supernatant was removed and the tissue was digested for $10 \mathrm{~min}$ with another $5 \mathrm{~mL}$ aliquot of trypsin solution, the suspension pipetted for $1 \mathrm{~min}$ and transferred to a centrifuge tube filled with culture medium [Dulbecco's Modified Eagle's Medium (DMEM) with 20\% fetal bovine serum (FBS)] to stop the digestion. This step was repeated 5 or 6 times until the tissue pieces were completely digested. All cell suspensions were then pooled and centrifuged at $1,000 \times \mathrm{g}$ for $10 \mathrm{~min}$ and the supernatants discarded. Cells were suspended, seeded on culture flasks, and incubated at $37{ }^{\circ} \mathrm{C}$ under $95 \%$ air, $5 \% \mathrm{CO}_{2}$ for $90 \mathrm{~min}$. The medium was removed and cultured in another flask. The medium was replaced $24 \mathrm{~h}$ later and the cells were marked as P1. Cells were cultured at $37{ }^{\circ} \mathrm{C}$ under $95 \%$ air, $5 \% \mathrm{CO}_{2}$ and passaged by digestion with $0.25 \%$ trypsin when cells reached $70 \%$ confluence. We used DMEM plus 10\% FBS for culture (10-12). Myocardial cells were identified by flow cytometry using cardiac troponin (cTn) as a marker. The in vitro ischemic model was established by culturing the cells without glucose or serum, under hypoxia $\left(5 \% \mathrm{CO}_{2}\right.$ and $\left.95 \% \mathrm{~N}_{2}\right)$ for $2 \mathrm{~h}$.

\section{Silencing and overexpression of TauT in primary cardiac myocytes using a lentivirus}

A small interfering RNA (siRNA) sequence complementarily 
binding to rat TauT (NM_017206.1) was selected. The target sequences of siRNA (5'-GGTTGTCTACTTCACTGCT-3') were homologous to TauT. The oligonucleotide templates of these short hairpin RNA (shRNA) were chemically synthesized and cloned into the linear pSIH1-H1-copGFP shRNA Vector (System Biosciences, Palo Alto, CA, USA), obtained by digestion with BamH I and EcoR I (Takara, Dalian, China) and purification by agarose gel electrophoresis. An invalid siRNA sequence (5'-GTTGTCATGTCTATCTCGC-3') was used as an NC (negative control). The CDS (coding sequence) of rat TauT was amplified using the primers 5'-GGAATTCGC CACCATGGCCACCAAGGAGAAG-3' and 5'-CGGGATC CTCACATCATGGTCTCCAC-3', which contain an EcoRI cutting site, and Kozak sequence, and a Bam HI cutting site, respectively. The complementary DNA (cDNA) was prepared by reverse transcription of RNA isolated from rat brain tissue. The polymerase chain reaction (PCR) product was digested and cloned into a pcDH1-CMV lentiviral expression vector (System Biosciences). The recombinant vector was named pcDH1-TauT. The products of the vectors were confirmed by DNA sequencing and endotoxin-free DNA was prepared.

Packaging of the lentivirus was performed in the 293TN virus packaging cell line (System Biosciences). A day before transfection, 293TN cells were seeded into $10 \mathrm{~cm}$ dishes. A $2 \mu \mathrm{g}$ sample of each shRNA and expression vector and $10 \mu \mathrm{g}$ pPACK Packaging Plasmid Mix (System Biosciences) were co-transfected using Lipofectamine 2000 (Invitrogen, Carlsbad, CA, USA) according to the manufacturer's protocol. The medium was replaced with DMEM with $1 \%$ FBS. After $48 \mathrm{~h}$, the supernatant was harvested and then clarified by centrifugation at $5,000 \times \mathrm{g}$ at $4{ }^{\circ} \mathrm{C}$ for $5 \mathrm{~min}$ and filtration with a $0.45 \mu \mathrm{m}$ polyvinylidene fluoride (PVDF) membrane (Millipore, Burlington, MA, USA). The viral titer was determined by gradient dilution. The packaged lentiviruses (Lv) were named Lv-shRNA-TauT, Lv-NC, and Lv-TauT.

The $\mathrm{P} 2$ rat myocardial cells in the logarithmic phase were seeded on 6 -well plates at $5 \times 10^{5}$ cells/well. A day later, the virus suspension was added at a multiplicity of infection (MOI) of 20. The infection efficiency was evaluated by observing the fluorescent mark at $72 \mathrm{~h}$ after infection. Total RNA and total protein were isolated from the cells and, respectively, subjected to real-time PCR for TauT or western blotting.

\section{Establishment of in vitro MI model and taurine treatment}

The $\mathrm{P} 3$ rat myocardial cells and transgenic cell lines were suspended after trypsin digestion and the number of viable cells was counted by trypan blue staining. Cells were suspended in DMEM containing 10\% FBS at a concentration of $1 \times 10^{5}$ cells $/ \mathrm{mL}$. The cells were seeded on 6 -well plates at $2 \mathrm{~mL} /$ well and cultured overnight under normal conditions. Next, all medium was replaced with fresh serum-free DMEM. For the MI model, cells were exposed for $2 \mathrm{~h}$ to hypoxia $\left(5 \% \mathrm{CO}_{2}+95 \% \mathrm{~N}_{2}\right)$. For pretreatment with taurine $(2,5$, or $12.5 \mathrm{mM})$, cells were cultured in DMEM containing taurine for $1 \mathrm{~h}$ and then subjected to hypoxia followed by reoxygenation. The cells were divided into the following 8 groups: control, $\mathrm{MI}$ treatment, taurine $(2 \mathrm{mM})$ pretreatment and $\mathrm{MI}$, taurine $(5 \mathrm{mM})$ pretreatment and MI, taurine $(12.5 \mathrm{mM})$ pretreatment and MI, Lv-NC infection and taurine $(12.5 \mathrm{mM})$ pretreatment and MI, Lv-shRNA- TauT infection and taurine $(12.5 \mathrm{mM})$ pretreatment, and $\mathrm{MI}$ and $\mathrm{Lv}$ - TauT infection and taurine $(12.5 \mathrm{mM})$ pretreatment and MI.

\section{Detection of taurine content and TauT, CDO and CSD protein expression}

After $2 \mathrm{~h} \mathrm{MI}$, cells were collected and taurine content was detected by HLPC. Total protein was extracted from the cells and TauT, CDO, and CSD proteins in each sample were detected by western blotting.

\section{Cell proliferation assay}

Cell culture was performed as described, except that cells were seeded on 96 -well plates, $100 \mu \mathrm{L} /$ well. At $2 \mathrm{~h}$ after MI treatment, cell proliferation was determined using the Cell Counting Kit-8 (Dojindo, Kumamoto, Japan), The CCK-8 solution $(10 \mu \mathrm{L})$ was added to each well and the cells cultured under normal conditions for an additional $4 \mathrm{~h}$ before measurement of absorbance at $450 \mathrm{~nm}$.

\section{Assessment of metabolic indicators associated with myocardial cell injury}

At $2 \mathrm{~h}$ after MI treatment, the medium was harvested and centrifuged at $1,000 \times \mathrm{g}$ for $2 \mathrm{~min}$. Supernatants were then assayed for LDH, CK, and cTnI on a BT-3000 (Biotecnica).

\section{Detection of intracellular calcium concentrations and L-type calcium channel}

At $2 \mathrm{~h}$ after MI treatment, the cells were collected and 
suspended in $10 \mu \mathrm{M}$ Fluo-3 (Dojindo; diluted in serum-free medium) and incubated at $37^{\circ} \mathrm{C}$ for $20 \mathrm{~min}$, with shaking every 3 or 5 mins. Cells were washed 3 times with serumfree medium to remove extracellular Fluo-3, then examined by flow cytometry FACSCanto [Becton, Dickinson and Co., Biosciences (BD), Franklin Lakes, NJ, USA] with excitation at $488 \mathrm{~nm}$ and emission at $525 \mathrm{~nm}$. Cells were then harvested and total protein extracted to detect L-type calcium channel by western blotting.

\section{Detection of apoptosis and expression of apoptosis-related proteins}

After $2 \mathrm{~h} \mathrm{MI}$ treatment, myocardial cells were isolated and assessed for apoptosis. An Annexin V-FITC Apoptosis Detection Kit II (BD) was used. The cells were washed with Dulbecco's phosphate-puffered saline (dPBS) twice, collected by centrifugation at 2,000 $\times \mathrm{g}$ for $5 \mathrm{~min}$ and suspended in $50 \mu \mathrm{L}$ binding buffer. Annexin V-FITC $(5 \mu \mathrm{L})$ was added, samples were incubated for $10 \mathrm{~min}$, and then $5 \mu \mathrm{L}$ propidium iodide (PI) was added. Samples were analyzed on the FACS Calibur (BD), with excitation and emission wavelengths of 488 and $530 \mathrm{~nm}$, respectively, using the FITC (FL1) channel and PI (FL2) channel. Total protein was also extracted from the cells and the Bcl-2 and BAX proteins were analyzed by western blotting.

\section{Measurement of taurine concentrations in tissue, plasma and cells by HPLC}

The main apparatus and reagents used included the following: Agilent 1100 HPLC system, Chemstation chromatography workstation, acetonitrile HPLC grade (Thermo Fisher Scientific, Waltham, MA, USA) and formic acid HPLC grade (Sigma-Aldrich, St. Louis, MO, USA). Taurine standard material, purity $>99 \%$, batch number, T0625 (Sigma-Aldrich).

\section{Chromatographic conditions, solution preparation, and processing of plasma, tissue and cells}

The chromatographic conditions were as follows: Kromasil C18 column $(250 \mathrm{~mm} \times 4.6 \mathrm{~mm}, 5 \mu \mathrm{m})$; mobile phase A, $0.05 \mathrm{~mol} / \mathrm{L}$ sodium acetate solution $(\mathrm{pH} 6.5)$; mobile phase $\mathrm{B}$, acetonitrile: water (1:1); gradient elution, flow rate $1 \mathrm{~mL} / \mathrm{min}$, column temperature $30^{\circ} \mathrm{C}$, detector wavelength, $360 \mathrm{~nm}$; injection volume, $20 \mu \mathrm{L}$.

For the plasma sample processing, a $500 \mu \mathrm{L}$ aliquot of plasma was mixed with $500 \mu \mathrm{L}$ acetonitrile, vortexed for $10 \mathrm{~s}$ and centrifuged at 4,000 $\times \mathrm{g}$ for $5 \mathrm{~min}$. The supernatant $(600 \mu \mathrm{L})$ was mixed with $600 \mu \mathrm{L}$ sodium bicarbonate and $375 \mu \mathrm{L}$ 1-Fluoro-2,4-dinitrobenzene (DNFB) and incubated at $60{ }^{\circ} \mathrm{C}$ for $1 \mathrm{~h}$ in the dark. Next, the volume was adjusted to $5 \mathrm{~mL}$ with buffer and the sample filtered through a membrane. A $20 \mu \mathrm{L}$ aliquot was injected for HPLC.

For tissue sample processing, a $100 \mu \mathrm{L}$ aliquot of each homogenized tissue sample was mixed with $150 \mu \mathrm{L}$ spike solution $(25 \mu \mathrm{g} / \mathrm{mL})$, then $3 \mathrm{~mL}$ of methanol:acetonitrile (1:9) was added. Tubes were vortexed for $1 \mathrm{~min}$, allowed to stand for $5 \mathrm{~min}$, then centrifuged at 3,500 $\times \mathrm{g}$ for $10 \mathrm{~min}$. The supernatants were removed, incubated at $60^{\circ} \mathrm{C}$, and dried under nitrogen. The residues were each dissolved in $1.5 \mathrm{~mL}$ mobile phase and centrifuged at $15,000 \times \mathrm{g}$ for $10 \mathrm{~min}$. Supernatants $(20 \mu \mathrm{L})$ were analyzed by HPLC.

During cell processing, culture medium was discarded and cells washed with phosphate-buffered saline (PBS), scraped into a $1.5 \mathrm{~mL}$ centrifuge tube, and centrifuged at $1,500 \times \mathrm{g}$ for $5 \mathrm{~min}$. The supernatant was discarded and cells were mixed with $500 \mu \mathrm{L} 0.5 \%$ cell lysis solution. Samples were centrifuged at $3,000 \times \mathrm{g}$ for $10 \mathrm{~min}$ and the supernatants, representing intracellular solution, were collected for analysis. Intracellular solution $(1 \mathrm{~mL})$ and extracellular solution $(1 \mathrm{~mL})$ were each mixed with $1.5 \mathrm{~mL}$ ethyl acetate, vortexed, and centrifuged at $10,000 \times \mathrm{g}$ for $10 \mathrm{~min}$. The supernatants were each transferred to a new $1.5 \mathrm{~mL}$ tube and the solvent dried under nitrogen at $37{ }^{\circ} \mathrm{C}$. The residues were redissolved in $100 \mu \mathrm{L}$ methanol and centrifuged at $10,000 \times \mathrm{g}$ for $10 \mathrm{~min}$. The intracellular and extracellular solutions were mixed and centrifuged at 15,000 $\times \mathrm{g}$ for $10 \mathrm{~min}$. Each supernatant $(20 \mu \mathrm{L})$ was analyzed by HPLC.

The taurine assay was performed by preparing a $400 \mu \mathrm{g} / \mathrm{mL}$ reference solution by diluting taurine stock solution and this was serially diluted (2-fold dilution) and assayed for taurine by HPLC. A linear regression was performed by plotting the peak area $(\mathrm{A})$ of taurine against the concentration $(\mathrm{C})$, using the formula: $\mathrm{C}=0.12 \mathrm{~A}+1.61$ $(r>0.9999)$. Plasma, tissue, and cell samples were assayed for taurine by HPLC.

\section{Protein levels in tissues and cells by western blotting}

Total protein was extracted from cells using a mammalian protein extraction reagent (M-PER) (Pierce, Rockford, IL, USA) or from rat myocardial tissue using a tissue protein extraction reagent (Pierce). Equal amounts of protein (20 $\mu \mathrm{g}$ 
per lane) estimated by a bicinchoninic acid (BCA) protein assay kit (Pierce) were separated on (11\%) sodium dodecyl sulfate polyacrylamide gel electrophoresis (SDS-PAGE) gels and bands transferred to nitrocellulose membranes. Blots were probed with monoclonal antibodies against human cardiac L-type calcium channels (1:300), Bcl-2 (1:500), BAX (1:600), or $\beta$-actin $(1: 1,200)$ (Santa Cruz Biotechnology, Santa Cruz, CA, USA). They were then washed and incubated with horseradish peroxidase (HRP)-conjugated anti-mouse/rabbit secondary antibody (Santa Cruz). After washing the blots, the stained bands were detected by chemiluminescence and imaged with $\mathrm{X}$-ray films. We used $\beta$-actin was as an endogenous reference for normalization.

\section{TauT mRNA levels in cells were detected by real-time PCR}

Total RNA was isolated with Trizol Reagent (Invitrogen) according to the manufacturer's instructions and reverse transcribed into cDNA using M-MLV Reverse Transcriptase and Random9 primer (Takara Bio, Kusatsu, Siga, Japan). The following specific primers were used for quantitative PCR of rat TauT (Forward: 5'-GAGCGGCCTGCCTGTGTTT-3', Reverse: 5' CCCAGGCCAGGATGACGATGTAGT-3'), CDO (Forward: 5'-GAAGCCTACGAGAGCAATCCT-3 ', Reverse: 5'- TCACCCCAGCACAGAATCATC-3'), CSD (Forward: 5'-GGCCGGGCGCATCATTACG-3', Reverse: 5'-AAGACCCCATCCCCAGTGTTCC-3') and $\beta$-actin (Forward: 5'-TTCCAGTGACTCCACGTGC-3', Reverse: 5' - AACTTTGGGCCTGTGCCGAAGGGT-3'). The lengths of the amplified products were 167, 125, 138, and $215 \mathrm{bp}$, respectively. Real-time PCR was performed using SYBR Premix Ex Taq ${ }^{\text {TM }}$ kit and the TP800 System (Takara). The cDNA from $200 \mathrm{ng}$ total RNA was used as the template. The PCR reactions were performed under the following conditions: 40 cycles of denaturation at $95{ }^{\circ} \mathrm{C}$ for $10 \mathrm{~s}$, annealing at $60{ }^{\circ} \mathrm{C}$ for $20 \mathrm{~s}$, and extension at $72{ }^{\circ} \mathrm{C}$ for 20 s. The TauT mRNA levels were normalized using the delta-delta-Ct method, to the expression of an endogenous housekeeping gene, $\beta$-actin.

\section{Statistical analysis}

All data were expressed as means \pm standard deviation (SD) and were analyzed by one-way analysis of variance (ANOVA). The least significant difference (LSD) was used for multiple comparisons between any 2 means. A $\mathrm{P}$ value $<0.05$ was considered statistically significant. All statistical analyses were performed using SPSS 13.0 software (IBM Corp., Armonk, NY, USA).

\section{Results}

\section{Assay for taurine levels in myocardial tissue and plasma samples}

The HPLC assay results showed that, at $0.5 \mathrm{~h}$ after ischemia, the taurine concentration was decreased in myocardial tissue from the MI group ( $\mathrm{P}<0.01$, vs. sham or taurine groups). Taurine treatment also increased taurine levels $(\mathrm{P}<0.01$, vs. ischemia), and taurine levels in the mild ischemia group were slightly higher than in the ischemia group $(\mathrm{P}<0.05$, vs. ischemia) (Figure 1A, left). At $2 \mathrm{~h}$ after ischemia, changes in taurine content in myocardial tissue were similar to those observed at $0.5 \mathrm{~h}$ after ischemia (Figure $1 A$, right). The same was true of the plasma taurine content (Figure 1B).

\section{Myocardial infarct area and metabolic indicators of myocardial injury}

At $2 \mathrm{~h}$ post MI treatment, the levels of LDH, CK, and cTnI in the myocardium in the $\mathrm{MI}$ group were higher than those in the sham-operated group $(\mathrm{P}<0.05)$ (Figure $2 A)$. Taurine treatment attenuated these increases $(\mathrm{P}<0.05)$. Levels of the indicators were lower in the mild MI group than in the MI group $(\mathrm{P}<0.05)$. Myocardial infarct areas in the 5 groups were $0.19 \% \pm 0.28 \%$ (sham), $0.85 \% \pm 0.42 \%$ (taurine), $66.13 \% \pm 9.73 \%(\mathrm{MI}), 44.51 \% \pm 3.81 \%$ (taurine $+\mathrm{MI})$, and $48.91 \% \pm 6.12 \%$ (Mild MI). Myocardial infarct areas were greater in the MI, taurine $+\mathrm{MI}$, and mild $\mathrm{MI}$ groups than in the sham and taurine groups (Figure $2 B, \mathrm{P}<0.05$ vs. sham or taurine groups). There were no significant differences between the sham and taurine groups $(\mathrm{P}>0.05)$.

\section{Changes in proteins associated with taurine synthesis in myocardial tissue}

By western blotting, at $2 \mathrm{~h}$ after MI treatment, compared with the sham group, the MI group had lower levels of TauT, CDO, and CSD in myocardial tissue $(\mathrm{P}<0.01)$. Taurine pretreatment increased the levels of all proteins $(\mathrm{P}<0.01$, vs. MI group). The levels of TauT, CDO, and CSD were higher in the Mild MI group than in the $\mathrm{MI}$ group $(\mathrm{P}<0.05)$ (Figure 3A). The Bcl-2 levels were decreased in the MI group $(\mathrm{P}<0.05)$ compared with the sham-operated group and taurine groups. Taurine treatment partly reversed this decrease 
A

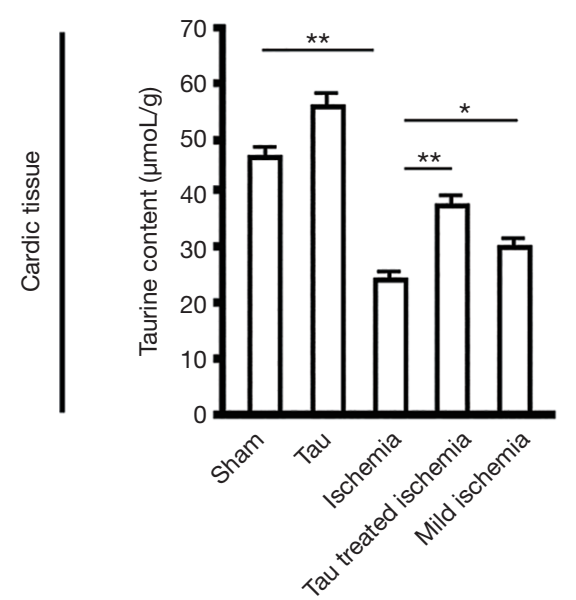

B

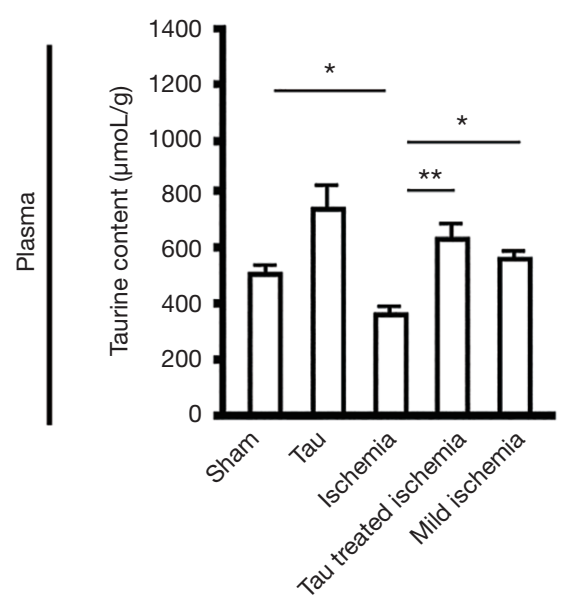

$2 \mathrm{~h}$ after modeling

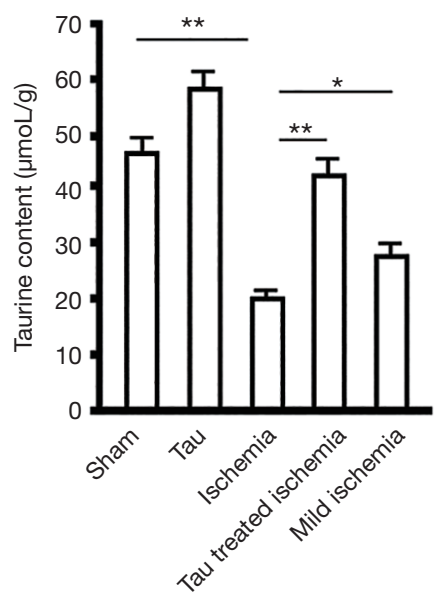

$2 \mathrm{~h}$ after modeling

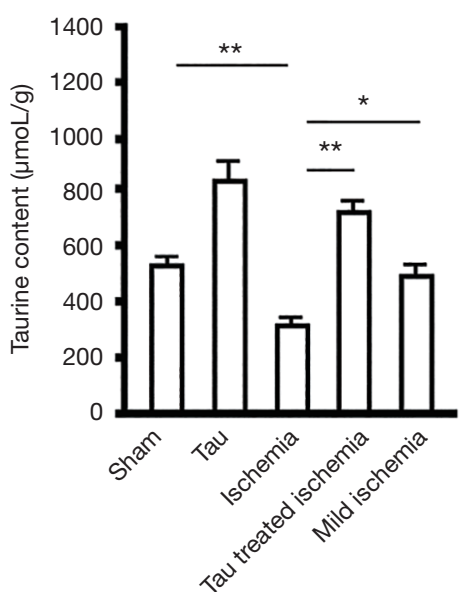

Figure 1 Taurine levels in myocardium and plasma. (A) Taurine levels in myocardium at $0.5 \mathrm{~h}$ (left) or $2 \mathrm{~h}$ (right) after ischemia. (B) Plasma taurine levels at $0.5 \mathrm{~h}$ (left) or $2 \mathrm{~h}$ (right) after ischemia. Data are means $\pm \mathrm{SD}$ of at least 3 independent experiments $(\mathrm{n}=12)$. ${ }^{*} \mathrm{P}<0.05$; ${ }^{* *} \mathrm{P}<0.01$. SD, standard deviation.

( $\mathrm{P}<0.05$, vs. MI group). The level of Bcl-2 was slightly higher in the Mild MI group than in the ischemia group $(\mathrm{P}<0.05)$. The change in BAX was opposite to that of Bcl-2 levels (Figure 3B). No significant differences were observed in BAX or $\mathrm{Bcl}-2$ levels between the sham and taurine groups $(\mathrm{P}<0.05)$.

\section{Purity of primary myocardial cells, lentiviral infection of cells, and gene intervention efficiency}

Based on the percentage of troponin in positive cells, calculated by flow cytometry, the purity of P2 cardiac myocytes was $88.91 \%$ (Figure $4 A$ ). Highly efficient gene delivery is essential for effective interference. We overcame difficulties in transfecting primary myocardial cells using a standard lentiviral system (Figure 4B), observing green fluorescent protein (GFP) expression in more than $90 \%$ of the cells. The lentiviral approach produced good results for both overexpression and knockdown of TauT. By western blotting, Tau T expression in the overexpression groups was $4.96 \pm 0.96$ times as high as in the control cell group. The expression of TauT in the knockdown groups was $0.12 \pm 0.01$ times as high as in the control cell group (Figure $4 C$ ), with significant differences between the genetic intervention and control cell groups $(\mathrm{P}<0.05)$. There were no 
A

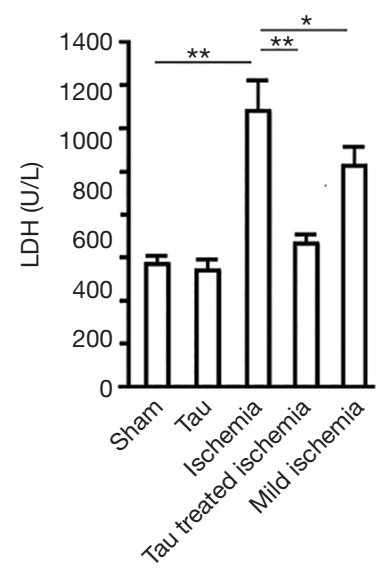

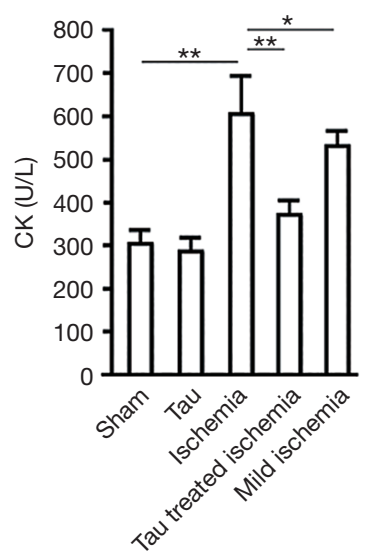

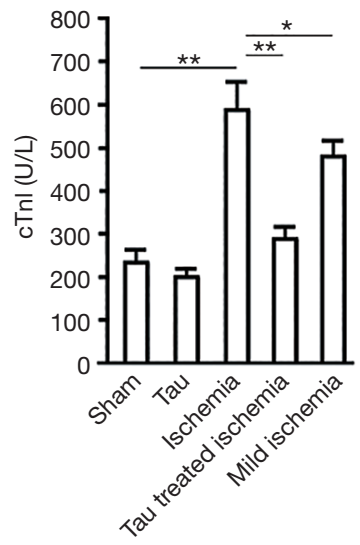

B
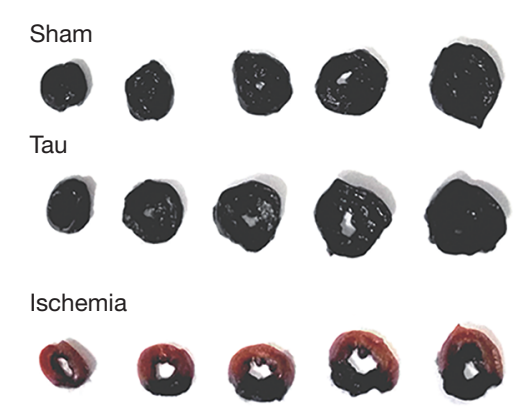

Tau treated ischemia

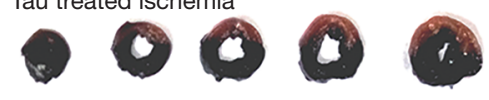

Mild ischemia

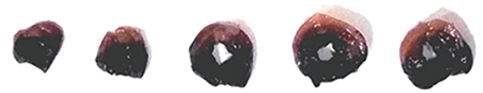

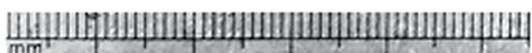
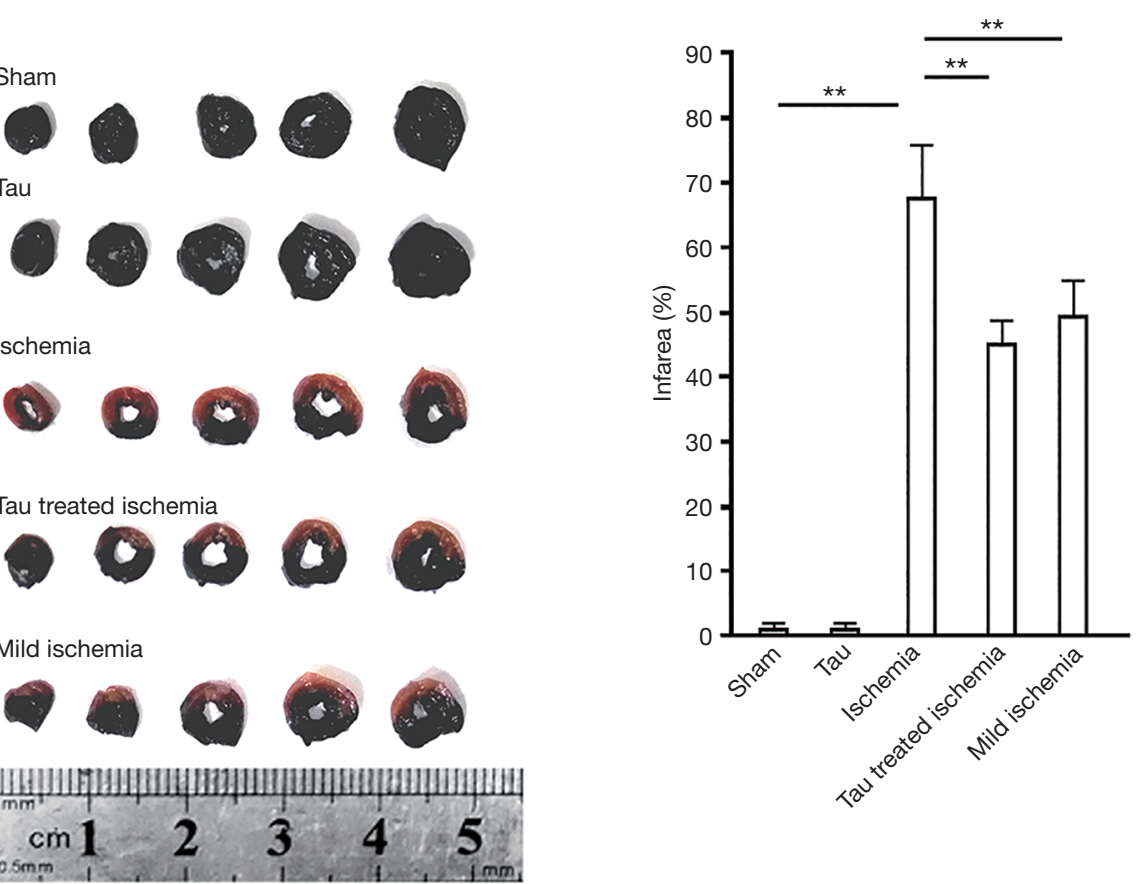

Figure 2 Levels of metabolic indicators in rat myocardial tissue and myocardial infarct areas. (A) LDH, CK, and cTnI were assayed in rat myocardial tissues. (B) Left, EB staining of cardiac muscle; right, inter-group comparison of myocardial infarct areas. Results are means \pm $\mathrm{SD}(\mathrm{n}=12) .{ }^{*} \mathrm{P}<0.05,{ }^{* *} \mathrm{P}<0.01$. LDH, lactate dehydrogenase; $\mathrm{CK}$, creatine kinase; cTnI, cardiac troponin I; EB, Evan's blue; SD, standard deviation.

significant differences in TauT expression in the $\mathrm{Lv}-\mathrm{NC}$ and control cell groups $(\mathrm{P}>0.05)$. By fluorescence quantitative reverse transcription (qRT)-PCR, TauT mRNA levels were similar to those of the protein (Figure 4D).

\section{Effects of TauT genetic intervention on the metabolism of taurine and related proteins in myocardial cells}

To elucidate the role of TauT in taurine transport into cells, we subjected myocardial cells to TauT silencing or overexpression and then exposed them to MI for $2 \mathrm{~h}$. Cells were harvested and the levels of taurine and TauT, CDO, and CSD proteins were analyzed by HPLC and western blotting, respectively. Compared with the control group, the MI group had significantly less taurine $(\mathrm{P}<0.01)$. Pretreatment with 5 or $12.5 \mathrm{mM}$ taurine increased the taurine content $(\mathrm{P}<0.01$, vs. MI group). Depletion of Tau $\mathrm{T}$ decreased and overexpression of TauT increased 
A

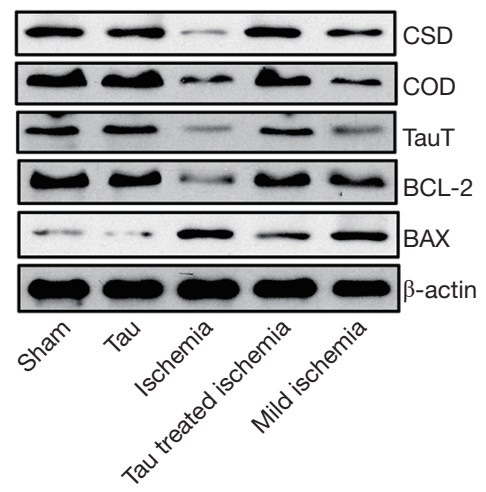

B

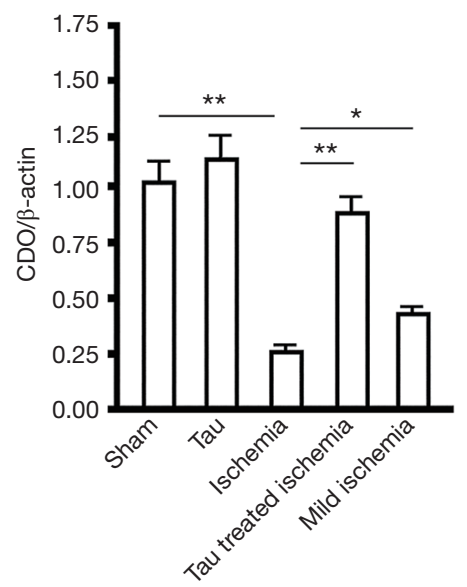

C

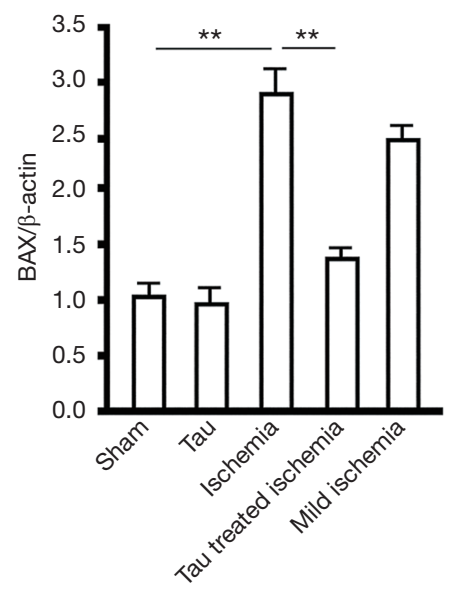

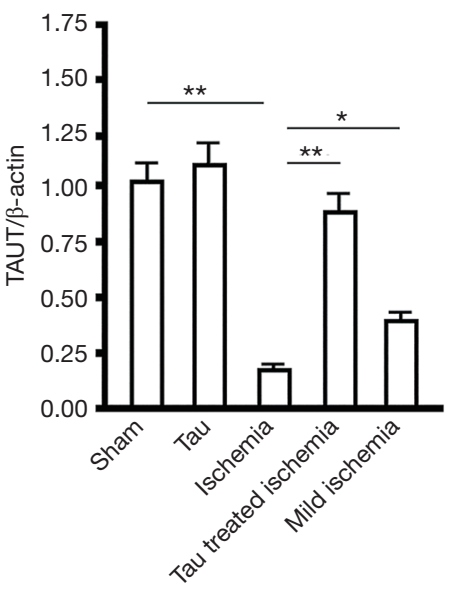
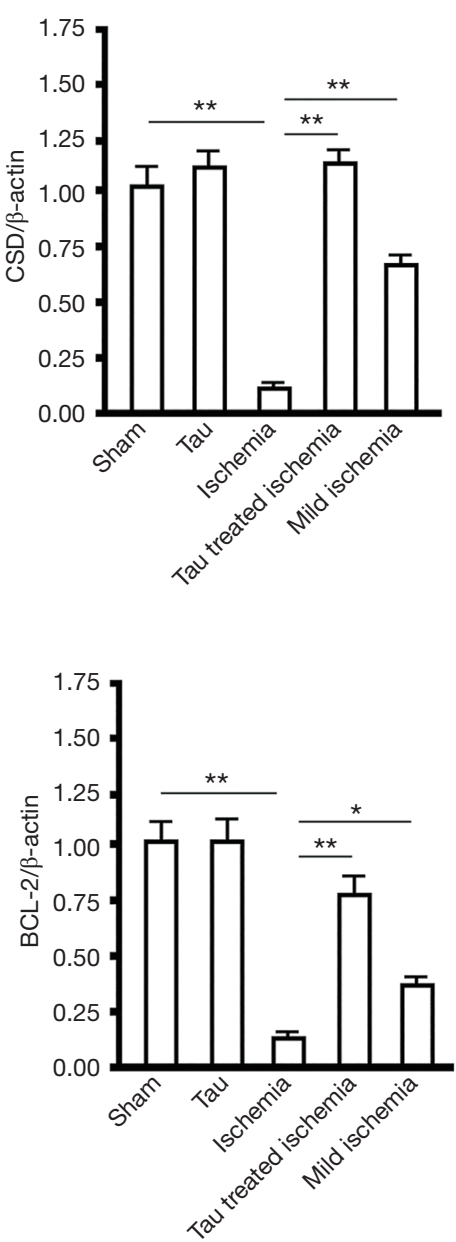

Figure 3 Expression of proteins involved in synthesis and transport of taurine and apoptosis-associated proteins in myocardium. (A) Western blotting for TauT, CDO, and CSD proteins in rat myocardial tissue. Upper, optical density analysis; lower, images showing stained bands. $\beta$-actin served as the reference. (B) Western blotting for Bcl-2 and BAX proteins in rat myocardial tissue. Upper, optical density analysis; lower, images showing stained bands. $\beta$-actin served as the reference. Data are means \pm SD from at least 3 separate replicates. ${ }^{*} \mathrm{P}<0.05$, ${ }^{* *} \mathrm{P}<0.01$. TauT, taurine transporter; CDO, cysteine dioxygenase; CSD, cysteine sulfinate decarboxylase; Bcl-2, B-cell lymphoma- $2 ; \mathrm{BAX}$, Bcl-2 associated $\mathrm{X}$ protein; SD, standard deviation. 
A
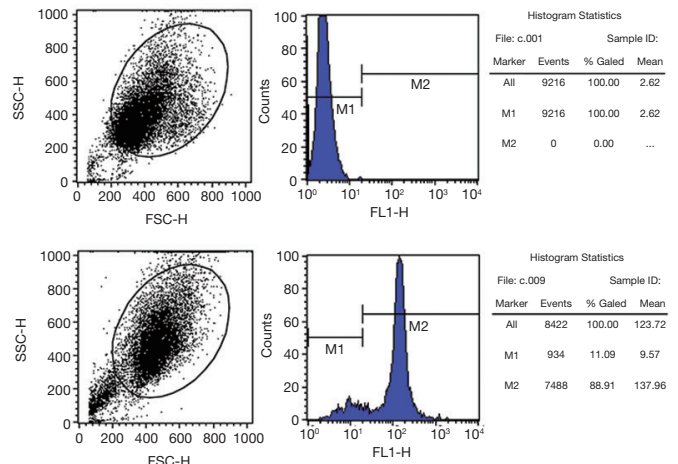

B

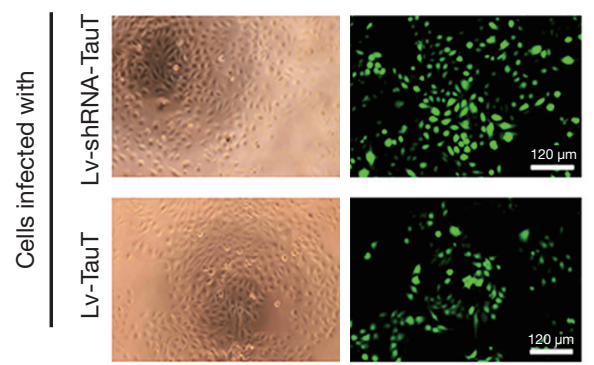

C

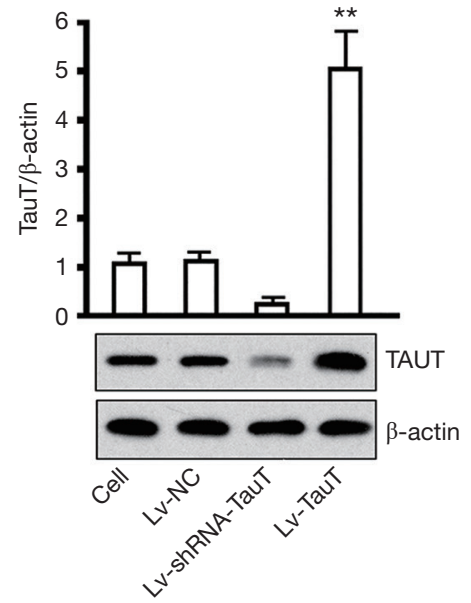

D

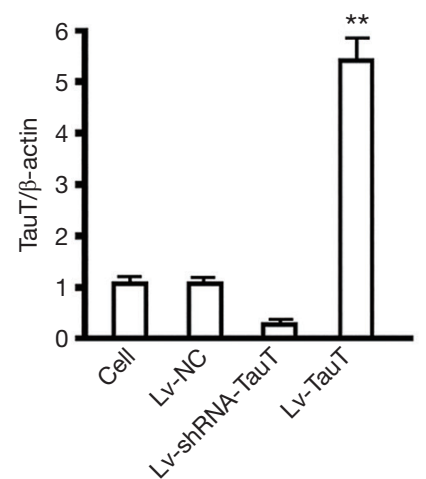

Figure 4 Purity and infection efficiency of primary myocardial cells and TauT gene intervention efficiency. (A) Upper, control cells with low troponin expression; lower, cell counts of troponin-positive myocardial cells. The $\mathrm{x}$-axis shows fluorescence intensity (FITC) and the y-axis shows cell numbers. (B) Left, cells viewed by bright-field microscopy; right, cells viewed by fluorescence microscopy. The infection efficiency was estimated by dividing the number of cells expressing the fluorescent marker by the total number of cells in the same field and 5 fields were randomly selected for the estimation. Myocardial cells infected with Lv-shRNA-TauT(lower) or Lv-TauT (upper) for $72 \mathrm{~h}, \mathrm{MOI}=20$. (C) Expression of TauT measured by western blotting. Lower, images of stained bands; upper, optical density analysis of 3 proteins, with $\beta$-actin serving as the reference. (D) TauT mRNA levels measured by real-time PCR. Data are means \pm SD from at least 3 separate replicates. ${ }^{* *} \mathrm{P}<0.01$, vs. control cells or cells infected with $\mathrm{Lv}-\mathrm{NC}$. TauT, taurine transporter; MOI, multiplicity of infection; mRNA, messenger RNA; PCR, polymerase chain reaction; SD, standard deviation.

intracellular taurine levels, when compared with the $12.5 \mathrm{mM}$ taurine pretreated group $(\mathrm{P}<0.01$, vs. $12.5 \mathrm{mM}$ taurine + MI group) (Figure $5 A$ ). By western blotting, compared with those in the control group, myocardial cells in the MI group had significantly lower TauT levels $(\mathrm{P}<0.01)$ and pretreatment with $12.5 \mathrm{mM}$ taurine increased TauT levels $(\mathrm{P}<0.01$, vs. MI group). Silencing of TauT and overexpression of TauT decreased and increased intracellular taurine, respectively $(\mathrm{P}<0.01$, vs. the $12.5 \mathrm{mM}$ taurine $+\mathrm{MI}$ group). Western blotting also showed similar trends in CDO and CSD levels among these groups (Figure 5B).
Effects of TauT intervention on cell proliferation, apoptosis, and concentration of calcium and its regulating proteins in myocardial cells

Based on CCK- 8 assays, MI treatment decreased cell proliferation at $24-72 \mathrm{~h}(\mathrm{P}<0.05$, vs. control cell group, $72 \mathrm{~h})$ and taurine pretreatment partly restored cell proliferation to control levels $(\mathrm{P}<0.05$, vs. MI group, $72 \mathrm{~h})$. There were no significant differences between the control cell and taurine $+\mathrm{MI}$ groups $(\mathrm{P}>0.05)$ (Figure 6A). Measurements of metabolic indicators (Figure $6 \mathrm{~B}$ ) showed that MI treatment increased LDH, CK, and cTnI levels at 24, 48, and $72 \mathrm{~h}$ 
A

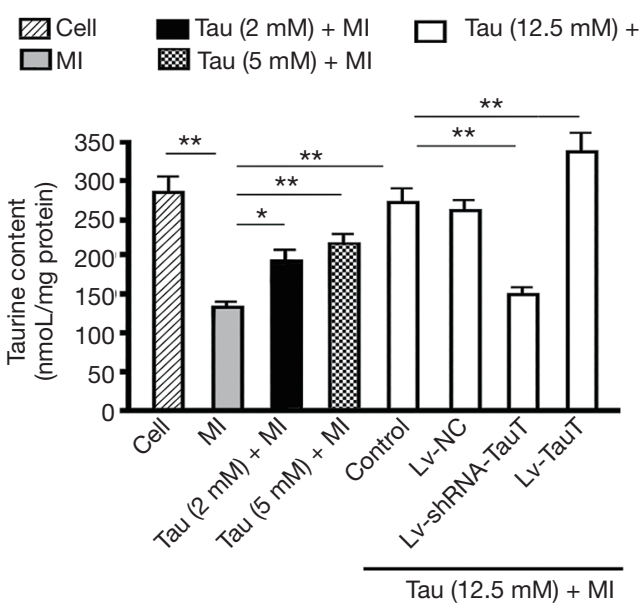

B
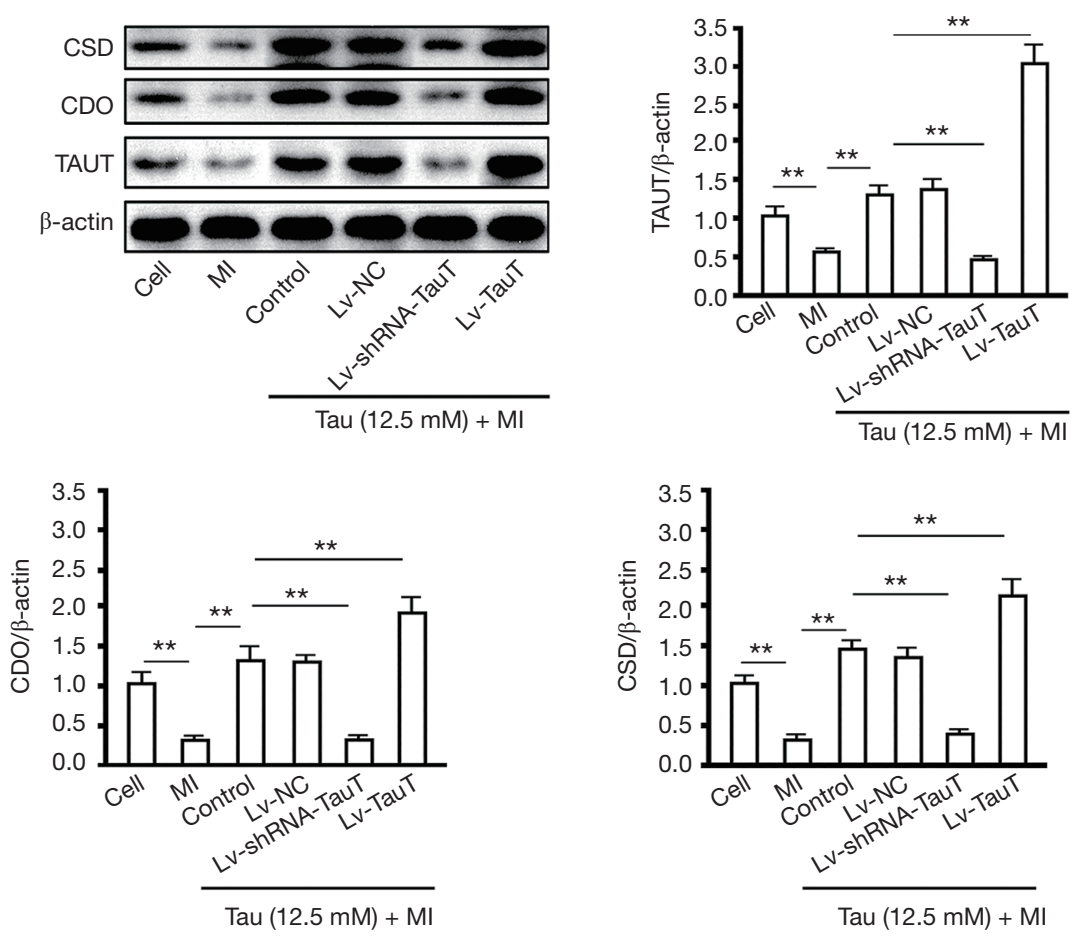

Figure 5 Levels of taurine and TauT, CDO, and CSD proteins in myocardial cells. (A) Taurine contents in the indicated cells. (B) Western blotting for TauT, CDO, and CSD in myocardial cells; upper, optical density analysis; lower, images of stained bands. $\beta$-actin served as the reference. Data are means $\pm \mathrm{SD}$ from at least 3 separate replicates. ${ }^{*} \mathrm{P}<0.05,{ }^{* *} \mathrm{P}<0.01$. TauT, taurine transporter; CDO, cysteine dioxygenase; CSD, cysteine sulfinate decarboxylase; SD, standard deviation.

$(\mathrm{P}<0.05)$, and taurine treatment attenuated this increase $(\mathrm{P}<0.01)$. The presence of $\mathrm{MI}$ induced clearly detectable apoptosis in rat myocardial cells and this was inhibited by taurine pretreatment (Figure 6C). The apoptosis rates of the 5 groups were $10.25 \% \pm 1.79 \%$ (Control), $67.48 \% \pm 7.86 \%$ (MI), $44.48 \% \pm 7.86 \%$ ( $2 \mathrm{mM}$ taurine $+\mathrm{MI}), 37.70 \% \pm 8.38 \%$ (5 $\mathrm{mM}$ taurine+ MI), and $15.86 \% \pm 5.09 \%(12.5 \mathrm{mM}$ taurine
$+\mathrm{MI})$, indicating that taurine suppressed apoptosis in a concentration-dependent manner. We found that MI also led to $\mathrm{Ca}^{2+}$ accumulation in myocardial cells and this was inhibited by taurine pretreatment (Figure 6D). Similarly, calcium binding protein was downregulated by taurine pretreatment in a concentration-dependent manner, and taurine pretreatment also increased $\mathrm{Bcl}-2$ expression and 
A

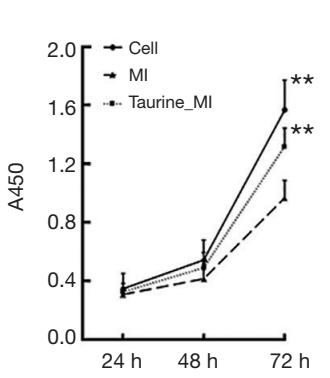

C

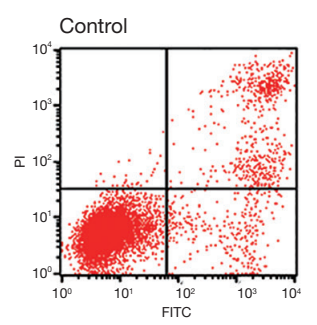

D

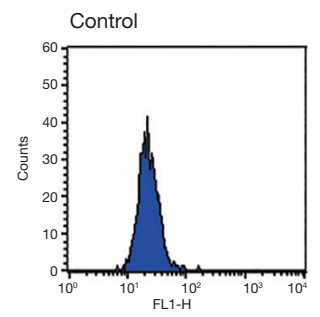

$\mathrm{E}$

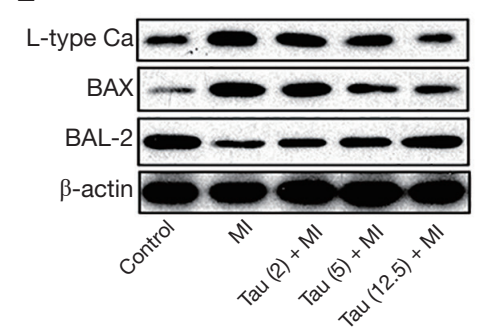

B
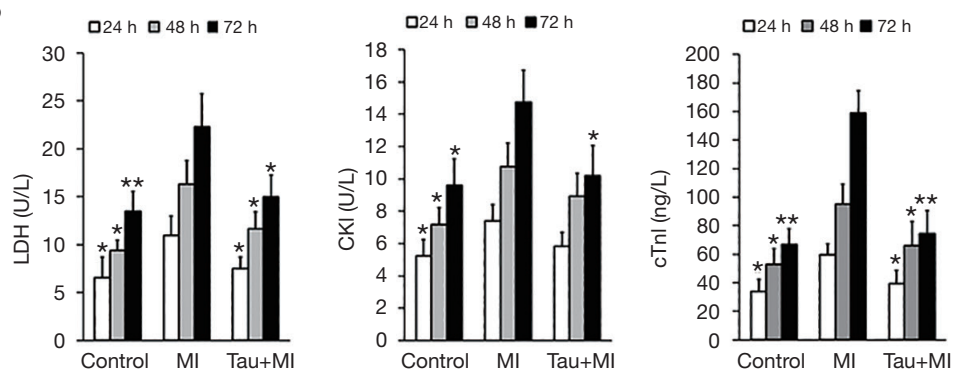
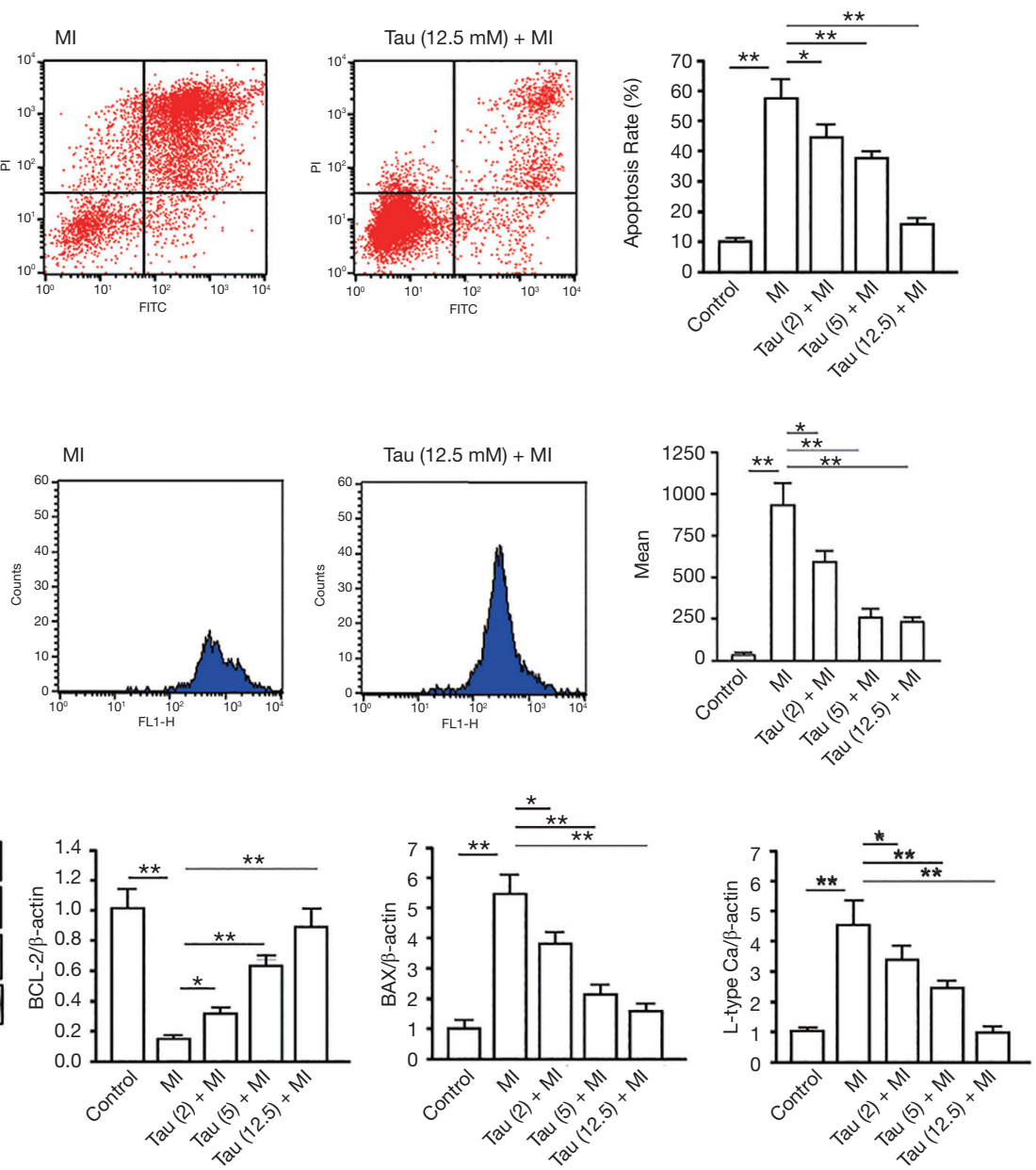

Figure 6 Proliferation, apoptosis, metabolic indicators, and calcium ion concentrations in myocardial cells. (A) Proliferation of myocardial cells after $2 \mathrm{~h} \mathrm{MI}$ treatment. The $\mathrm{x}$-axis shows cell groups and the y-axis shows absorbance values at $450 \mathrm{~nm}$, which were linearly correlated with cell proliferation. (B) Metabolic indicators in myocardial cells after $2 \mathrm{~h} \mathrm{MI} \mathrm{treatment.} \mathrm{(C)} \mathrm{Apoptosis} \mathrm{in} \mathrm{myocardial} \mathrm{cells} \mathrm{after} 2 \mathrm{~h}$ MI treatment. The $\mathrm{x}$-axis shows FITC staining, the $\mathrm{y}$-axis shows PI and the right lower and right upper quadrants show the earlier and later apoptotic cells, respectively. The bar chart shows statistical data on apoptosis rates. (D) Intracellular calcium levels, the $\mathrm{x}$-axis shows fluorescence intensity and the y-axis shows cell counts. The bar chart shows statistical analysis of intracellular calcium ion concentrations. (E) Measurements of calcium binding protein (L-type Ca), Bcl-2, and BAX with $\beta$-actin serving as the reference. Data are means \pm SD from at least 3 separate replicates. ${ }^{*} \mathrm{P}<0.05,{ }^{* *} \mathrm{P}<0.01$. MI, myocardial ischemia; Bcl-2, B-cell lymphoma-2; BAX, Bcl-2 associated $\mathrm{X}$ protein; PI, propidium iodide; SD, standard deviation. 
decreased BAX expression in myocardial cells and, thus, suppressed MI-induced apoptosis (Figure 6E).

\section{Discussion}

As a common cardiac disease, MI directly affects the metabolism and biology of myocardial cells and, thus, remarkably impacts cardiac function (13-15). The manifestations of MI include angina, arrhythmia, and cardiac insufficiency, often severely impacting patient quality of life. Taurine was shown to improve MI-induced injuries, but its mechanism of action remains largely unknown. Based on the results of our mechanistic study, further improving taurine availability and efficiency is a clear future direction for taurine-based treatments for MI.

Transmembrane transport of taurine helps maintain its homeostasis, enabling its biological function, and studies have demonstrated that TauT is crucial for taurine homeostasis. There are 2 processes which contribute to taurine accumulation in cells; intracellular biosynthesis, and transport by TauT from the plasma. Generally, the latter process impacts intracellular taurine levels the most (16). Taurine is synthesized from methionine and cysteine in the presence of the cofactor pyridoxal 5'-phosphate, through decarboxylation and oxidation, which mainly take place in the liver, brain, and heart (17). First, methionine and cysteine are converted to cysteine sulfinate by CSD, then into hypotaurine through decarboxylation, and, finally, into taurine by oxidation. The expression and activities of $\mathrm{CDO}$ and CSD are regarded as important indicators of taurine synthesis. Taurine can be released by neurogliocytes to different encephalic regions in response to extracellular hypotonicity. Adenosine triphosphate (ATP) plays a crucial role in cellular osmoregulation. Taurine is similarly important for myocardial cells. Taurine has been reported to stabilize membranes by preventing decreases in $\mathrm{Na}^{+} / \mathrm{K}^{+}$-ATPase activity, which can directly reflect taurine release (18-21).

Taurine levels are decreased faster than those of troponin in myocardial cells during acute ischemia. The fact that taurine can be detected by magnetic resonance spectroscopy allows it to be used to monitor MI. How cellular taurine concentrations change remains unclear, but there is evidence for the involvement of decreased synthesis or transport of taurine. Decreased transport may be caused by attenuated TauT expression or activity (22-24). We previously examined the mRNA and protein levels of TauT in the myocardium from a rat model of acute $\mathrm{MI}$ and found that both were significantly decreased. We speculated that the decreased TauT expression contributed to the decrease in taurine levels during MI. However, whether decreased TauT activity and taurine synthesis are related, and the source and destination of taurine (the root cause of the decrease) require further investigation.

Taurine administration was shown to protect ischemic myocardium, but its optimal dose and mechanism of action remain largely unknown $(23,24)$. Our previous study also showed that taurine pretreatment elevated TauT mRNA and protein levels in the myocardium from the rat model of acute MI. This led us to investigate whether these changes had a concomitant or a causal relationship with myocardial injury, to provide more experimental evidence for improving cardiac function by taurine. We hypothesized that, if taurine treatment did increase the intracellular taurine concentration in myocardial cells by upregulating TauT expression, thus increasing cytoprotection, this would suggest new options for treating acute MI.

Certain other pathways may also help to protect myocardial cells from ischemia-induced injury. Ischemia decreases the taurine content in myocardial cells and subsequently impairs the function of the amino acid against ischemic injury. Hypoxia changes mitochondrial respiratory function, leading to oxidative stress, which in turn may damage the respiratory chain and induce apoptosis. During this process, a shortage of taurine would result in mitochondrial malfunction, as well as abnormal transcription and translation of mitochondrial genes. Moreover, studies have shown that taurine was involved, as a modifier of uridine, in the synthesis of mitochondrial transfer RNA (tRNA). In some mitochondrial diseases, for example mitochondrial myopathy, encephalopathy, lactic acidosis, and stroke-like episodes (MELAS) and myoclonic epilepsy with ragged-red fibers (MERRF), tRNA levels are decreased. Taurine accounts for about $50-60 \%$ of total free amino acids in myocardial cells and has many biological effects, such as inhibiting apoptosis, stabilizing membranes, scavenging oxygen radicals, regulating osmotic pressure, and maintaining calcium homeostasis. Thus, changes in taurine levels may significantly impact cell function. Taurine inhibits homocysteine (Hcy)-induced endoplasmic reticulum stress (ERS) and ERS-induced apoptosis $(25,26)$. Therefore, taurine may protect cells by inhibiting ERS in ischemic myocardial cells. In addition, in neurons, taurine mainly stimulates calcium release from intracellular stores, regulating calcium ion levels through a 2-way regulation, thus preventing calcium overload, and protecting neurons, therefore improving learning and memory (27-29). Calcium/calmodulin-dependent protein kinase $(\mathrm{CaMK})$ is a ubiquitous $\mathrm{Ca}^{2+}$ regulator and 
can phosphorylate a variety of substrates, thereby regulating their functions. Mainly expressed in the heart, $\mathrm{CaMKII}$ is a polymer consisting of $6-12$ subunits, coded by $\alpha, \beta, \gamma$, and $\delta$ genes. It is one of the key proteins regulating $\mathrm{Ca}^{2+}$ homeostasis and myocardial contractility by phosphorylating ryanodine receptors (RyR), sarcoendoplasmic reticulum calcium transport ATPase (SERCA), phospholamban (PLB), and L-type calcium channel (LTCC), which are important for the regulation of $\mathrm{Ca}^{2+}$ levels and excitation-contraction coupling. It remains to be studied whether CaMKII levels or its activity would be increased by taurine treatment to maintain $\mathrm{Ca}^{2+}$ homeostasis by phosphorylation (30).

\section{Conclusions}

Our study verified the relationship between decreased taurine levels in myocardial cells and the time of exposure to ischemia, as well as between taurine levels and the severity of myocardial ischemic injury. This indicated that taurine levels might be useful for early diagnosis of acute MI. We also explored the mechanism causing decreased taurine levels during acute MI, investigating the role of Tau T in taurinemediated protection of myocardial cells during ischemia. Our results demonstrated that TauT may be a useful genetic target for further improving the efficiency of taurine against MI, for example, upregulation of Tau T through a genetic engineering approach could be beneficial. Our mechanistic study also showed that the Blc-2/BAX apoptotic pathway and calcium binding protein regulation were involved in the effects of taurine. Taken together, our findings provided a theoretical basis for using taurine to treat MI. Research examining changes in taurine absorption and synthesis could help identify optimal routes of administration for improving taurine-based treatment regimens.

\section{Acknowledgments}

Funding: This research was funded by the National Science Foundation of China (81370342), Heilongjiang Province Science Foundation (H2015079, H2018067), The Fundamental Research Funds for the Universities of Heilongjiang Province (2017-KYYWFMY-0650, 0660, and 0661), and Graduate Innovation Funds of Mudanjiang Medical University (2019YJSCX-11MY).

\section{Footnote}

Reporting Checklist: The authors have completed the
ARRIVE reporting checklist. Available at https://dx.doi. org/10.21037/atm-21-2481

Data Sharing Statement: Available at https://dx.doi. org/10.21037/atm-21-2481

Conflicts of Interest: All authors have completed the ICMJE uniform disclosure form (available at https://dx.doi. org/10.21037/atm-21-2481). The authors have no conflicts of interest to declare.

Ethical Statement: The authors are accountable for all aspects of the work in ensuring that questions related to the accuracy or integrity of any part of the work are appropriately investigated and resolved. All studies involving animal samples were conducted in compliance with the National Guidelines for the Care and Use of Animals in Biomedical Research and were reviewed and approved by the Ethics Committee of Mudanjiang Medical University (No. 2018030097).

Open Access Statement: This is an Open Access article distributed in accordance with the Creative Commons Attribution-NonCommercial-NoDerivs 4.0 International License (CC BY-NC-ND 4.0), which permits the noncommercial replication and distribution of the article with the strict proviso that no changes or edits are made and the original work is properly cited (including links to both the formal publication through the relevant DOI and the license). See: https://creativecommons.org/licenses/by-nc-nd/4.0/.

\section{References}

1. Anderson CMH, Howard A, Walters JRF, et al. Taurine Uptake across the Human Intestinal Brush-Border Membrane Is via Two Transporters: H+-Coupled PAT1 (SLC36A1) and Na+- and Cl--Dependent TauT (SLC6A6). J Physiol 2009;587:731-44.

2. Warskulat U, Flögel U, Jacoby C, et al. Taurine transporter knockout depletes muscle taurine levels and results in severe skeletal muscle impairment but leaves cardiac function uncompromised. FASEB J 2004;18:577-9.

3. Lombardini JB, Crass MF. Taurine and Myocardial Ischemia. Springer Netherlands, 1981;419-36.

4. Nathan RD, C. M. 3rd. Electrophysiological effects of taurine in cardiac Purkinje fibers and myocardial taurine loss during ischemia. Is there a relationship? Adv Exp Med Biol 1981;139:165-80. 
5. Yang X, Fu J, Wan H, et al. Protective Roles and Mechanisms of Taurine on Myocardial Hypoxia/ Reoxygenation-Induced Apoptosis. Acta Cardiol Sin 2019 35:415-24.

6. Zhang Y, Yang L, Yang YJ, et al. Low-dose taurine upregulates taurine transporter expression in acute myocardial ischemia. Int J Mol Med 2013;31:817-24.

7. TNP Johns, BJ Olson. Experimental Myocardial Infarction: I. A Method of Coronary Occlusion in Small Animals. Ann Surg 1954;140:675-82.

8. McFate Smith W. Epidemiology of congestive heart failure. Am J Cardiol 1985;55:A3-8.

9. Gay R, Gustafson TA, Goldman S, et al. Effects of L-thyroxine in rats with chronic heart failure after myocardial infarction. Am J Physiol 1987;253:341-6.

10. Tang S, Buriro R, Liu Z, et al. Localization and Expression of Hsp27 and $\alpha \mathrm{B}-$ Crystallin in Rat Primary Myocardial Cells during Heat Stress In Vitro. PLoS One 2013;8:e69066.

11. Liu JQ, S. Y. Methods of primary culturing myocardial cells of neonatal rat. Stud Trace Elem Heal 2012;87:567-80.

12. Banyasz T, Lozinskiy I, Payne CE, et al. Transformation of adult rat cardiac myocytes in primary culture. Exp Physiol 2008;93:370-82.

13. Schömig A. Catecholamines in myocardial ischemia. Systemic and cardiac release. Circulation 1990;82:II13-22.

14. Yu X, Sun X, Zhao M, et al. Propofol attenuates myocardial ischemia reperfusion injury partly through inhibition of resident cardiac mast cell activation. Int Immunopharmacol 2018;54:267-74.

15. La Rovere MT, Specchia G, Mortara A, et al. Baroreflex sensitivity, clinical correlates, and cardiovascular mortality among patients with a first myocardial infarction. A prospective study. Circulation 1988;78:816-24.

16. Huxtable RJ. Physiological actions of taurine. Physiol Rev 1992;72:101-63.

17. Pasantes-Morales H, Chatagner F, Mandel P. Synthesis of taurine in rat liver and brain in vivo. Neurochem Res 1980;5:441-51.

18. Li M, Reynolds CM, Sloboda DM, Gray C, et al. Effects of Taurine Supplementation on Hepatic Markers of Inflammation and Lipid Metabolism in Mothers and Offspring in the Setting of Maternal Obesity. PLoS One 2013;8:e76961.

19. Prentice H, Gharibani PM, Ma Z, et al. Neuroprotective Functions Through Inhibition of ER Stress by Taurine or Taurine Combination Treatments in a Rat Stroke Model.
Adv Exp Med Biol 2017;975:193-205.

20. Schuller-Levis GB, Park E. Taurine: New implications for an old amino acid. FEMS Microbiol Lett 2003;226:195-202.

21. Ueki I, Stipanuk MH. Enzymes of the taurine biosynthetic pathway are expressed in rat mammary gland. J Nutr 2007;137:1887-94.

22. Mal'Chikova LS, Elizarova EP, Smirnov VN. Taurine transport in the heart. Kardiologiia 1978;18:83-8.

23. Lambert IH, Hoffmann EK. Regulation of taurine transport in Ehrlich ascites tumor cells. J Membr Biol 1993;131:67-79.

24. Tomi M, Terayama T, Isobe T, et al. Function and regulation of taurine transport at the inner blood-retinal barrier. Microvasc Res 2007;73:100-6.

25. Nonaka H, Tsujino T, Watari Y, et al. Taurine prevents the decrease in expression and secretion of extracellular superoxide dismutase induced by homocysteine: Amelioration of homocysteine-induced endoplasmic reticulum stress by taurine. Circulation 2001;104:1165-70.

26. Men X, Han S, Gao J, et al. Taurine protects against lung damage following limb ischemia reperfusion in the rat by attenuating endoplasmic reticulum stress-induced apoptosis. Acta Orthop 2010;81:263-7.

27. Yamauchi, T. Neuronal Ca2+/calmodulin-dependent protein kinase II - discovery, progress in a quarter of a century, and perspective: implication for learning and memory. Biol Pharm Bull 2005;28:1342-54.

28. McGargill MA, Sharp LL, Bui JD, et al. Active Ca2+/ calmodulin-dependent protein kinase II gamma B impairs positive selection of $\mathrm{T}$ cells by modulating TCR signaling. J Immunol 2005;175:656-64.

29. Lin MY, Zal T, Ch'en IL, et al. A Pivotal Role for the Multifunctional Calcium/Calmodulin-Dependent Protein Kinase II in T Cells: From Activation to Unresponsiveness. J Immunol 2005;174:5583-92.

30. Anderson ME. Calmodulin kinase signaling in heart: An intriguing candidate target for therapy of myocardial dysfunction and arrhythmias. Pharmacol Ther 2005;106:39-55.

Cite this article as: Ren F, Liu X, Liu X, Cao Y, Liu L, Li X, Wu Y, Du S, Tian G, Hu J. In vitro and in vivo study on prevention of myocardial ischemic injury by taurine. Ann Trans Med 2021;9(12):984. doi: 10.21037/atm-21-2481 